\title{
Isolation and Characterization of Mutations in the $H X K 2$ Gene of Saccharomyces cerevisiae
}

\author{
HONG MA, ${ }^{1} \dagger$ LESLIE M. BLOOM, ${ }^{1,2}$ ZHIMIN ZHU, ${ }^{1} \ddagger$ CHRISTOPHER T. WALSH,$^{2}$ AND DAVID BOTSTEIN ${ }^{1} \S^{*}$ \\ Biology Department, Massachusetts Institute of Technology, Cambridge, Massachusetts 02139, ${ }^{1}$ and Department of \\ Biological Chemistry and Molecular Pharmacology, Harvard Medical School, Boston, Massachusetts $02115^{2}$
}

Received 16 March 1989/Accepted 11 August 1989

\begin{abstract}
Several hundred new mutations in the gene (HXK2) encoding hexokinase II of Saccharomyces cerevisiae were isolated, and a subset of them was mapped, resulting in a fine-structure genetic map. Among the mutations that were sequenced, 35 were independent missense mutations. The mutations were obtained by mutagenesis of cloned $H X K 2$ DNA carried on a low-copy-number plasmid vector and screened for a number of different phenotypes in yeast strains bearing chromosomal $h x k 1$ and $h x k 2$ null mutations. Some of these mutants were characterized both in vivo and in vitro; they displayed a wide spectrum of residual hexokinase activities, as indicated by three assays: in vitro enzyme activity, ability to grow on glucose and fructose, and ability to repress invertase production when growing on glucose. Of those that failed to support growth on fructose, only a small minority made normal-size, stable, and inactive protein. Analysis of the amino acid changes in these mutants in light of the crystallographically determined three-dimensional structure of hexokinase II suggests important roles in structure or catalysis for six amino acid residues, only two of which are near the active site.
\end{abstract}

Budding yeast (Saccharomyces cerevisiae) produces three different enzymes that can phosphorylate glucose and thus initiate glycolysis. Two of these (hexokinases I and II) phosphorylate fructose and mannose as well, allowing growth when either of these sugars is used as the sole source of carbon and energy; the third (glucokinase) phosphorylates only glucose and mannose $(43,44,49,50)$. The two hexokinases (encoded by the $H X K 1$ and $H X K 2$ genes $[25,28,66]$ ) are thus both dispensable for growth on glucose, but the cell requires one or the other for growth on fructose. The two hexokinases are not functionally interchangeable, however, as there are differences in the phenotypes of null mutations in the two genes, notably in the growth rate on glucose and the degree of remaining glucose repression (47).

Yeast hexokinase isozymes have been the subject of a considerable number of biochemical studies (for reviews, see references 17 and 59). The in vitro properties of the purified isoenzymes have been characterized previously (20-22, 69-71). Chemical modification studies demonstrated that a thiol group (55), a glutamyl residue (58), and at least one arginyl residue $(11,57)$ are essential for the catalytic activity of yeast hexokinase; these residues have not been specifically identified. The $\mathrm{pH}$ dependence of hexokinase catalytic activity (72) indicates that an acidic group is crucial for catalysis, further supporting a role for a glutamyl residue in catalysis.

The yeast hexokinases have also been studied extensively by X-ray crystallography. The three-dimensional structures of the hexokinase II monomer in a complex with the glucose analog $O$-toluoylglucosamine (67), its dimer without substrate $(4-6)$, and hexokinase I with glucose $(8,9)$ have been

\footnotetext{
* Corresponding author.

† Present address: Division of Biology, California Institute of Technology, Pasadena, CA 91125.

$\ddagger$ Present address: Department of Biological Chemistry and Molecular Pharmacology, Harvard Medical School, Boston, MA 02115.

$\S$ Present address: Genentech, Inc., 460 Point San Bruno Boulevard, South San Francisco, CA 94080.
}

determined. Glucose binding induces a conformational change in both hexokinase isozymes from the open to the closed form $(7,51)$. The structures of the enzymes have been refined (R. W. Harrison, Ph.D. dissertation, Yale University, New Haven, Conn., 1985) on the basis of X-ray diffraction data of $0.35-\mathrm{nm}$ resolution for hexokinase $\mathrm{I}$ and 0.21-nm resolution for hexokinase II, using the amino acid sequences derived from the DNA sequences of $H X K 1$ and HXK2 $(29,39,66)$. The refined structures identify several residues that can form hydrogen bonds with the sugar (or analog) substrate and may be important for binding, catalysis, or both.

Hexokinase II is also necessary for cells to maintain normal glucose repression; it is necessary for regulation of genes for enzymes such as invertase. Both point mutations $(23,24)$ and null mutations (47) in $H X K 2$ are known to block manifestation of glucose repression. Therefore, hexokinase II is a bifunctional protein, with effects in both glycolysis and glucose repression. It is not known, however, whether the involvement of hexokinase II in these two processes is mechanistically distinct. Point mutants of $H X K 2$ have been found to cause defects in glucose repression yet still retain hexose phosphorylating activity (24). These results led Entian and Frohlich to propose that hexokinase II has two domains, one for each function (24).

This proposed structure of hexokinase II may be dissected with mutational analysis. If hexokinase II indeed has two domains, there should be mutations that lead to repressiondefective and catalysis-functional hexokinase II and also those that affect catalysis but not repression. Since relatively little is known about the functions of individual amino acid residues in catalysis or in glucose repression by hexokinase II, we have undertaken random mutagenesis of $H X K 2$. Although a few residues potentially involved in substrate binding can be identified on the basis of the three-dimensional crystal structure, none of the residues involved in glucose repression are known. By using random mutagenesis and screening for various phenotypes, bias toward particular 
TABLE 1. Yeast strains

\begin{tabular}{|c|c|c|}
\hline Strain & Genotype $^{a}$ & $\begin{array}{l}\text { Reference } \\
\text { or source }\end{array}$ \\
\hline DBY1315 & MAT $\alpha$ ura3-52 leu2-3,2-112 lys $2-801 \mathrm{~g}$ & 47 \\
\hline & $\begin{array}{l}\text { MAT } \mathrm{h} \text { hk1::LEU2 hxk2-202 ura3-52 } \\
\text { leu2-3,2-112 lys2-801 gal2 }\end{array}$ & 47 \\
\hline DBY2053 & $\begin{array}{l}\text { MAT } \alpha \times k 1:: L E U 2 \text { ura3-52 leu2-3,2-112 } \\
\text { lys2-801 gal2 }\end{array}$ & 47 \\
\hline DBY2184 & $\begin{array}{l}\text { MAT } \mathrm{h} x \mathrm{k} 2-202 \text { ura3-52 leu2-3,2-112 } \\
\text { lys2-801 gal2 }\end{array}$ & 47 \\
\hline DBY2192 & $\begin{array}{l}\text { MAT } h x k 1:: L E U 2 \text { hxk2-202 ura3-52 } \\
\quad \text { leu2-3,2-112 GAL }\end{array}$ & This wor \\
\hline DBY2212 & $\begin{array}{l}\text { MATa hxk1::LEU2 hxk2-202 ura3-52 } \\
\text { lys2-801 his3-200 ade2-101 LEU2 } \\
\text { (pJP100, CYC1-lacZ }{ }^{+} \text {) leu2-3,2-112 } \\
\text { gallo-120 }\end{array}$ & $\mathrm{Tl}$ \\
\hline DBY2230 & $\begin{array}{l}\text { MATa hxk1::LEU2 hxk2-202 ura3-52 } \\
\text { leu2-3,2-112 lys2-801 his3-200 gallo- } \\
120 \text { gal80::HIS3 }\end{array}$ & This wo \\
\hline DBY2317 & 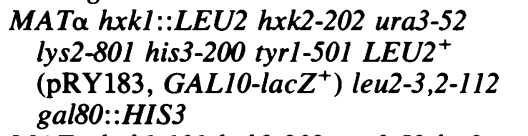 & 47 \\
\hline DBY 2809 & $\begin{array}{l}\text { MATa hxk1-101 hxk2-202 ura3-52 lys2- } \\
801 \text { leu2-3,2-112 his3-200 gallo-120 }\end{array}$ & This wor \\
\hline
\end{tabular}

${ }^{a}$ The $h x k 1-101$ null allele is an internal deletion of about 200 base pairs; it was generated in vitro by BAL 31 partial digestion at a Sall site in the coding region of $H X K 1$ on pRB1038, a derivative of YIp5 (12). The sources of other alleles have been described previously: ura3-52 (62); leu2-3,2-112 (12); lys2801(16); his3-200 (68); hxk1::LEU2, hxk2-202, LEU2 (pJP100, CYC1-lacZ ${ }^{+}$) leu2-3,2-112, LEU2 ${ }^{+}$(pRY183, GAL10-lac ${ }^{+}$) leu2-3,2-112, gall0-120, gal80: :HIS3, and tyrl-50I (47).

kinds of mutations or specific amino acid residues can be minimized.

In this paper, we describe the isolation, characterization, mapping, and sequencing of a large number of $h \times k 2$ mutations in the hope of revealing domains associated with a particular set of phenotypes. Our strategy was to induce the mutations in the cloned gene carried on a low-copy-number plasmid vector; to introduce the mutations into a $h x k l h x k 2$ double-null yeast strain and screen for a defect in either growth or glucose repression; to place the mutations on a fine-structure map of the $H X K 2$ gene; to analyze the phenotypes of a subset of particularly interesting mutations in vivo and in vitro; and to determine the DNA sequences of particularly interesting mutations.

The mutations we studied did not, in the end, provide evidence supporting a clear-cut domain structure separating the sugar-phosphorylating and glucose repression functions, although particular amino acid residues in the vicinity of the active site (as inferred from the crystal structure) are implicated in catalysis. The accompanying paper (46) reports a correlation between residual phosphorylation activity and residual glucose repression observed by using the mutations described here.

\section{MATERIALS AND METHODS}

Strains and plasmids. The yeast strains used are isogenic to S288C (MATa SUC2 gal2). The host strains for transformation are summarized in Table 1 ; the remaining strains are one or another of these host strains with a particular plasmid, usually carrying an allele of the $H X K 2$ gene. Escherichia coli $\mathrm{HB} 101$ (13) was used for amplification of mutagenized DNA and individual plasmids. $E$. coli DB4729 [endA thi hsdR $h s d M^{+} \Delta(s r l R-r e c A) 306$; from Barry Bochner] was used to obtain methylated DNA for transformation of $E$. coli DB6448. DB6448 (mutD5 rpsL aziR galU95; obtained from L. Enquist) was used to mutagenize pRB313. The mutD5 mutation (a dominant mutator) in DB6448 causes elevated frequency of spontaneous mutations, including transitions, transversions, and frameshift mutations $(18,19,26)$.

Plasmid YEp420 has been described previously (48). Plasmid pJJ101 (pRB529 [47]) is a derivative of YIp5 (12) with a 6.2-kilobase-pair (kb) ClaI-BamHI fragment containing the $H X K 1$ locus (containing a putative $A R S$ element $[\mathrm{H}$. Ma and D. Botstein, unpublished data]) cloned into the ClaI-BamHI sites. Plasmid pRB144 (Fig. 1) is a derivative of pBR328 with a 3.7-kb EcoRI fragment containing $H X K 2$ (66) in the EcoRI site. Plasmid pT7-2 (Fig. 2) was purchased from U.S. Biochemical Corp., Cleveland, Ohio (GeneScribe kit). Plasmid pSI4 (Fig. 3 [14]) was a gift from Mark Johnson.

Plasmid construction. Several plasmids were constructed in vitro (Fig. 1 to 3). Plasmid pRB1038 was constructed by using the method of homologous recombination of overlapping linear fragments in yeast cells (48). A Ura ${ }^{-}$yeast strain was transformed with (i) a URA3-containing fragment from YIp5 by digestion with BamHI and PvuII and (ii) circular pJJ101; then the plasmid was recovered from $\mathrm{Ura}^{+}$transformants. Plasmid pRB1167 was made in the same way by transforming a ura3-52 $h x k 1:: L E U 2 h x k 2-202$ strain with a mixture of (i) pRB976 carrying the $h x k 2-083$ allele linearized by digesting with $B g I I I$ and $X h o I$ restriction endonucleases and (ii) a $2 \mu \mathrm{m}$ sequence-containing fragment generated from YEp420 by cutting with EcoRV, PstI, and SmaI restriction enzymes. The transformants were selected for growth on medium lacking uracil; the new plasmid, pRB1167, was recovered in $E$. coli $\mathrm{HB} 101$, and its structure was confirmed by restriction analysis. A derivative of pSI 4 carrying $h x k 2$ 083 was constructed similarly by transforming yeast strain DBY2809 with a mixture of pRB701 (Fig. 3) linearized by cutting with SmaI enzyme and a 3.7-kb EcoRI fragment containing $h x k 2-083$, selecting for $\mathrm{Ura}^{+}$transformants.

Genetic and DNA manipulations and yeast transformation. Genetic manipulations in yeast cells were done as described previously (64). Yeast cells were transformed by a modification (T. Stearns, H. Ma, and D. Botstein, Methods Enzymol., in press) of the alkali cation method $(38,42)$. Plasmids were recovered from yeast strains as described previously (37). Sequencing was done directly from plasmid DNA by the double-strand procedure $(34,40)$ of the dideoxynucleotide termination method (63). The primers (HXK2 sequences) were made in a DNA synthesizer (Pharmacia, Inc., Piscataway, N.J.).

Mutagenesis. Plasmid pRB313 (modified in DB4729) was mutagenized by transforming the $E$. coli mutD strain DB6448 and then isolating plasmid DNA from independent transformant cultures. Plasmid pRB312 was mutagenized by the in vitro mutagenesis method of misincorporation by omission as previously described (65). Randomly generated small single-stranded gaps are repaired while omitting one of the four deoxyribonucleotides, thus forcing the misincorporation of nucleotides. The mutagenized plasmid DNA was used to transform $E$. coli, selecting for ampicillin resistance, in order to amplify mutagenized plasmids. E. coli DB6507 (53), a derivative of HB101 (13) with a Tn5 insertion in pyrF (pyrF74::Tn5), was used to estimate the mutation frequency of the mutagenized plasmids. Transformants of DB6507 with mutagenized plasmid DNA were selected for ampicillin resistance and then scored for growth without uracil. Because the yeast $U R A 3$ gene on the plasmid can complement the $E$. coli pyrF mutation (61), those $E$. coli transformants 

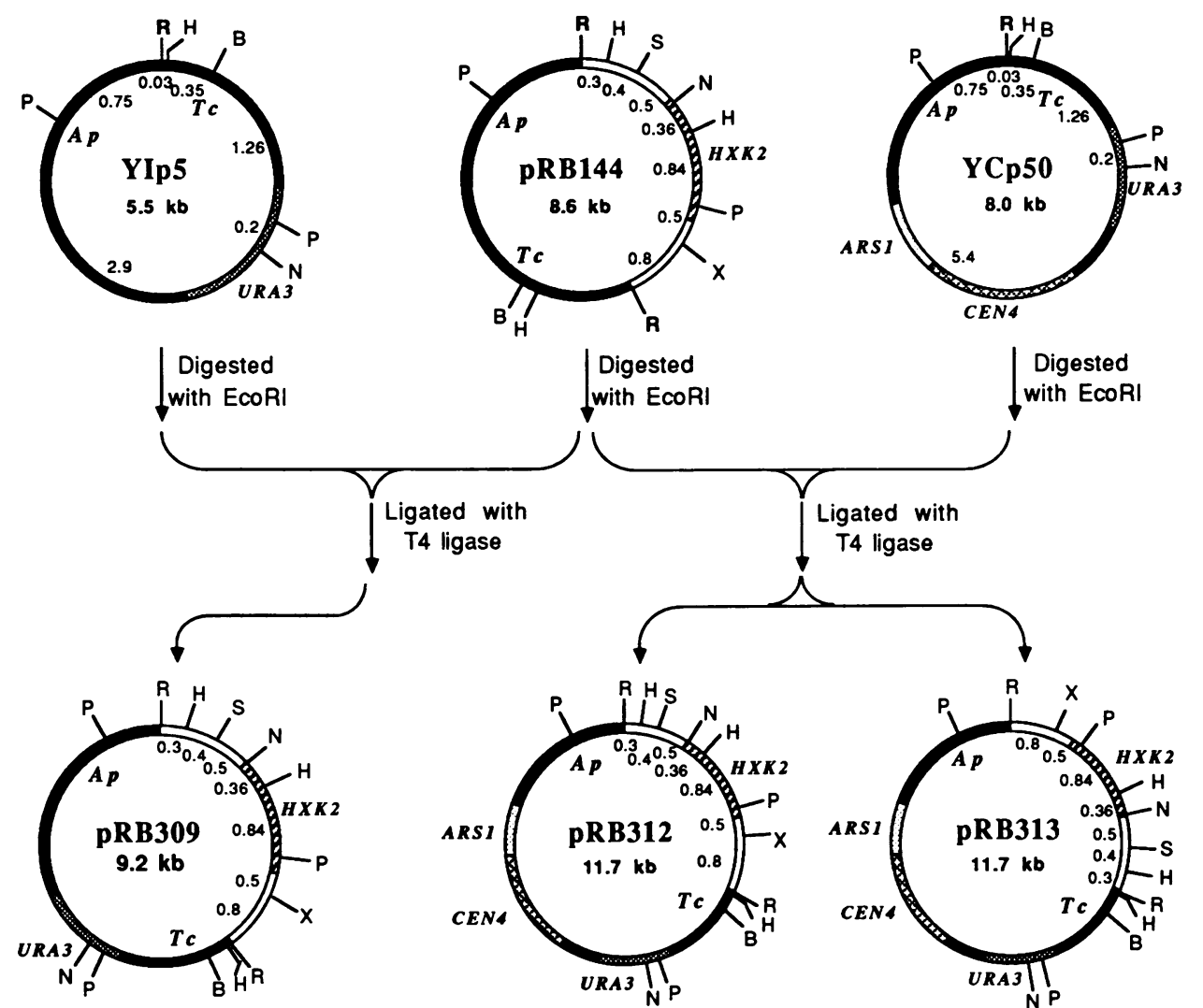

Ligated with T4 ligase

FIG. 1. Construction of pRB309, pRB312, and pRB313. A 3.7-kb EcoRI fragment containing the HXK2 locus was released from pRB144 (66) and then inserted into the EcoRI site either of YIp5 (12) to yield pRB309 or of YCp50 (see Fig. 2 in reference 48 for a detailed restriction map) to yield pRB312 and pRB313. Symbols: $\square$, pBR322 sequences; $\square, 5^{\prime}$ - and 3'-flanking sequences of $H X K 2$. Other regions are as labeled. Abbreviations for enzymes: B, BamHI; H, HindIII; N, NcoI; P, PstI; R, EcoRI; S, SacI; X, XbaI.

that receive a plasmid containing a functional $U R A 3$ gene can grow without uracil, whereas those having a plasmid carrying a defective ura3 gene cannot.

Mutant screening. The mutagenized plasmids were used to transform $h x k 1:: L E U 2$ hxk2-202 ura3-52 yeast strains (DBY2052 and DBY2212) to $\mathrm{Ura}^{+}$. Yeast transformants were then screened for mutant phenotypes by replica plating to media containing various carbon sources, including glucose, fructose, raffinose, galactose, or glycerol, at a $2 \%$ concentration. Those that grew on glucose but failed to grow like wild type on one or more of the other carbon sources were picked as mutant candidates. To maximize the differences between mutants and wild type, the plates either contained the respiration inhibitor antimycin $\mathbf{A}$ or were incubated anaerobically.

Additional screens for mutants that are defective in glucose repression were performed by replica plating yeast transformants to media containing a combination of a sugar and a nonmetabolizable glucose analog, such as $2 \%$ galactose plus $0.1 \%$ glucosamine or $2 \%$ raffinose plus $0.1 \%$ glucosamine. Glucosamine has a repressive effect similar to that of glucose but cannot be further metabolized to yield energy (27). Cells with a functional hexokinase II fail to grow on raffinose or galactose in the presence of glucosamine because synthesis of the enzymes needed for growth is repressed. Mutants that are defective in glucose repression should synthesize those enzymes and thus be able to utilize these carbon sources. Raffinose can be hydrolyzed relatively inefficiently by invertase to release fructose and melibiose. The latter is not used by the strains used in this study.
Therefore, cells need relatively high levels of invertase to hydrolyze enough raffinose for growth. Transformants were replica plated on glucosamine and either galactose or raffinose; those that showed better than wild-type growth were chosen as mutant candidates.

A screen for growth on raffinose and 2-deoxyglucose (73) was also used to select for $h x k 2$ mutants that are defective in glucose repression and retain some phosphorylation activity. The rationale for plating on raffinose and 2-deoxyglucose is based on the fact that 2-deoxyglucose has a toxic effect that can be relieved by glucose or fructose. Mutants that fail to repress the $S U C 2$ gene, a glucose repression-sensitive gene coding for invertase, will synthesize enough invertase for the hydrolysis of raffinose, thereby yielding fructose and relieving the toxicity of 2-deoxyglucose. If these mutants retain hexokinase activity, they can also use the fructose to support growth. The $\mathrm{Ura}^{+}$yeast transformants were collected into pools and grown in liquid medium for $8 \mathrm{~h}$ or overnight on plates with $8 \%$ glucose; they were then plated on medium containing $2 \%$ raffinose and $0.02 \% 2$-deoxyglucose, and colonies that grew were picked. This selection is not as stringent as we had hoped; sometimes mutants with very little hexokinase activity can still survive.

The phenotypes of the mutant candidates identified by these screens were rechecked. Plasmids were then recovered from those that retained their original phenotypes. The transformants with these newly isolated plasmids were then scored for the original phenotypes again. The transformants that behaved like the mutants candidates were chosen for further analysis. 

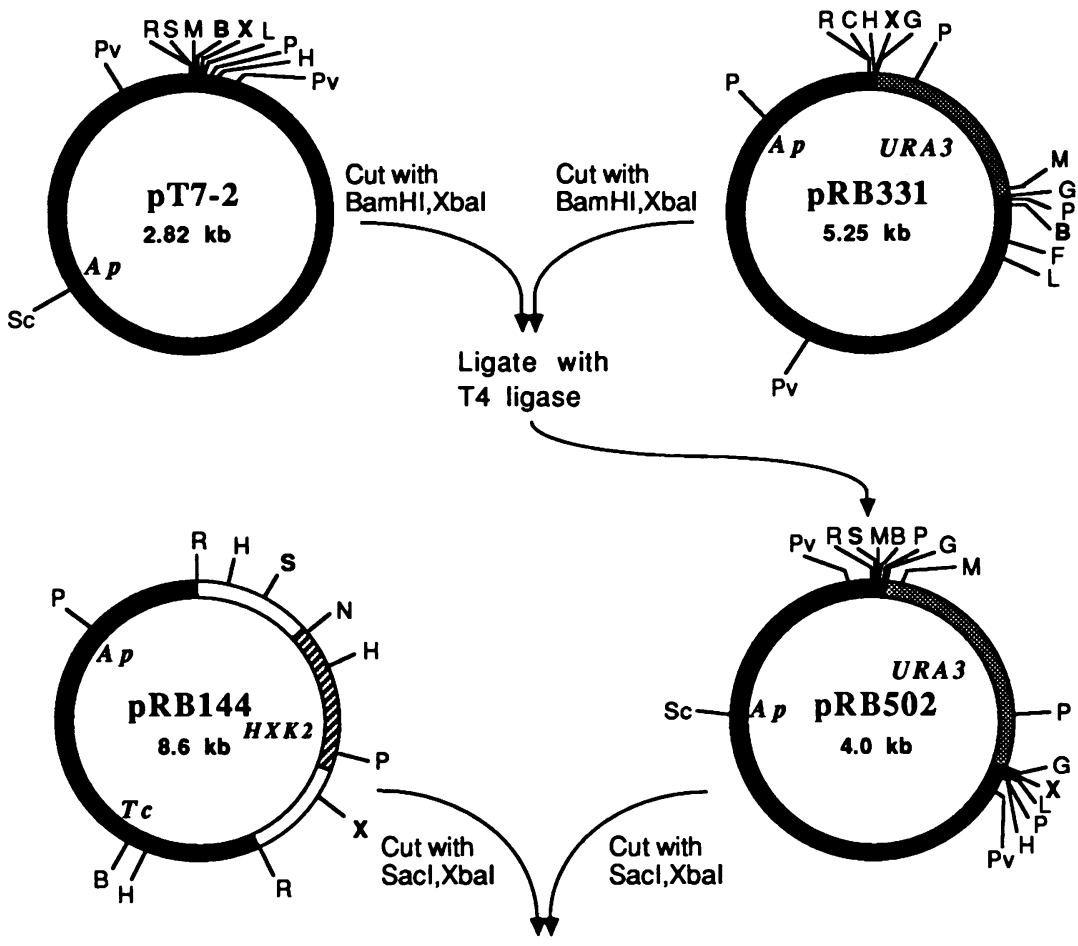

Ligate with

T4 ligase

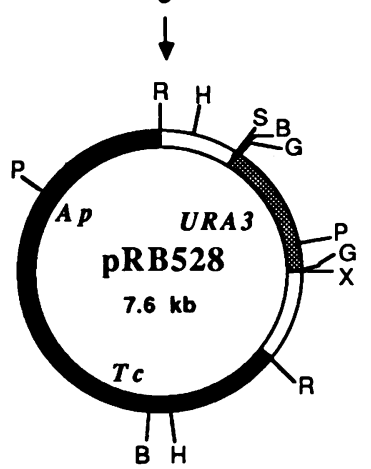

FIG. 2. Construction of pRB502 and pRB528. Plasmid pRB331 is a derivative of pPL7 with a 1.1-kb URA3 fragment, constructed by M. A. Hoyt in this laboratory; the URA3 1.1-kb HindIII fragment (60) was blunt ended, ligated with BgIII linkers, and then inserted into the BgIII site of pPL7. The URA3 gene was released from pRB331 by digestion with $X b a I$ and BamHI enzymes; then pRB502 was constructed by inserting the $U R A 3$ fragment into pT7-2 between the $X b a I$ and BamHI sites. Plasmid pRB528 was constructed from pRB144 by replacing a 2.2-kb SacI-XbaI fragment containing $H X K 2$ with the $U R A 3$ gene from pRB502. Symbols: $\square$, pBR322 sequences; $\square, 5^{\prime}$ - and 3'-flanking sequences of $H X K 2$. Other regions are as labeled. Abbreviations for enzymes: B, Bam HI; C, ClaI; F, SphI; G, BglII; H, HindIII; L, SalI; M, SmaI; N, NcoI; P, PstI; Pv, PvuII; R, EcoRI; S, SacI; Sc, ScaI; X, XbaI. The sites cut during construction are in boldface type. Not all restriction sites are shown.

Fine-structure deletion mapping. For the purpose of mapping the point mutations, deletions of $H X K 2$ starting in either the $5^{\prime}$ or $3^{\prime}$ region were generated from pRB309 (see reference 41 for details), and mapping experiments were carried out as described previously (41). Ura ${ }^{+}$transformants were selected and then scored for the wild-type growth phenotypes of hexokinase II by replica plating to fructose. Wild-type cells can grow on fructose at 26,30 , or $37^{\circ} \mathrm{C}$. For many mutations, the mutant either completely failed to grow on fructose or grew very poorly at $30^{\circ} \mathrm{C}$; the wild-type recombinants were scored at $30^{\circ} \mathrm{C}$. For mutants that grew well on fructose at $30^{\circ} \mathrm{C}$ and grew poorly on fructose at $37^{\circ} \mathrm{C}$, the wild-type recombinants were scored at $37^{\circ} \mathrm{C}$. The wild- type recombinants among the mapping transformants of still another set of mutations were scored on the basis of the fact that glucose repression protects cells carrying a gallo (epimerase) mutation from galactose poisoning by repressing expression of the GALl (kinase) gene. Yeast cells with a gallo mutation are sensitive to galactose if galactokinase is functional. Cells with normal glucose repression are not sensitive to galactose in the presence of glucose because glucose represses the synthesis of galactokinase. Therefore, cells with a wild-type $H X K 2$ gene can grow on medium with glucose and galactose even with a gallo mutation. On the other hand, gallo cells with $h x k 2$ alleles causing defects in glucose repression are sensitive to galactose even in the 

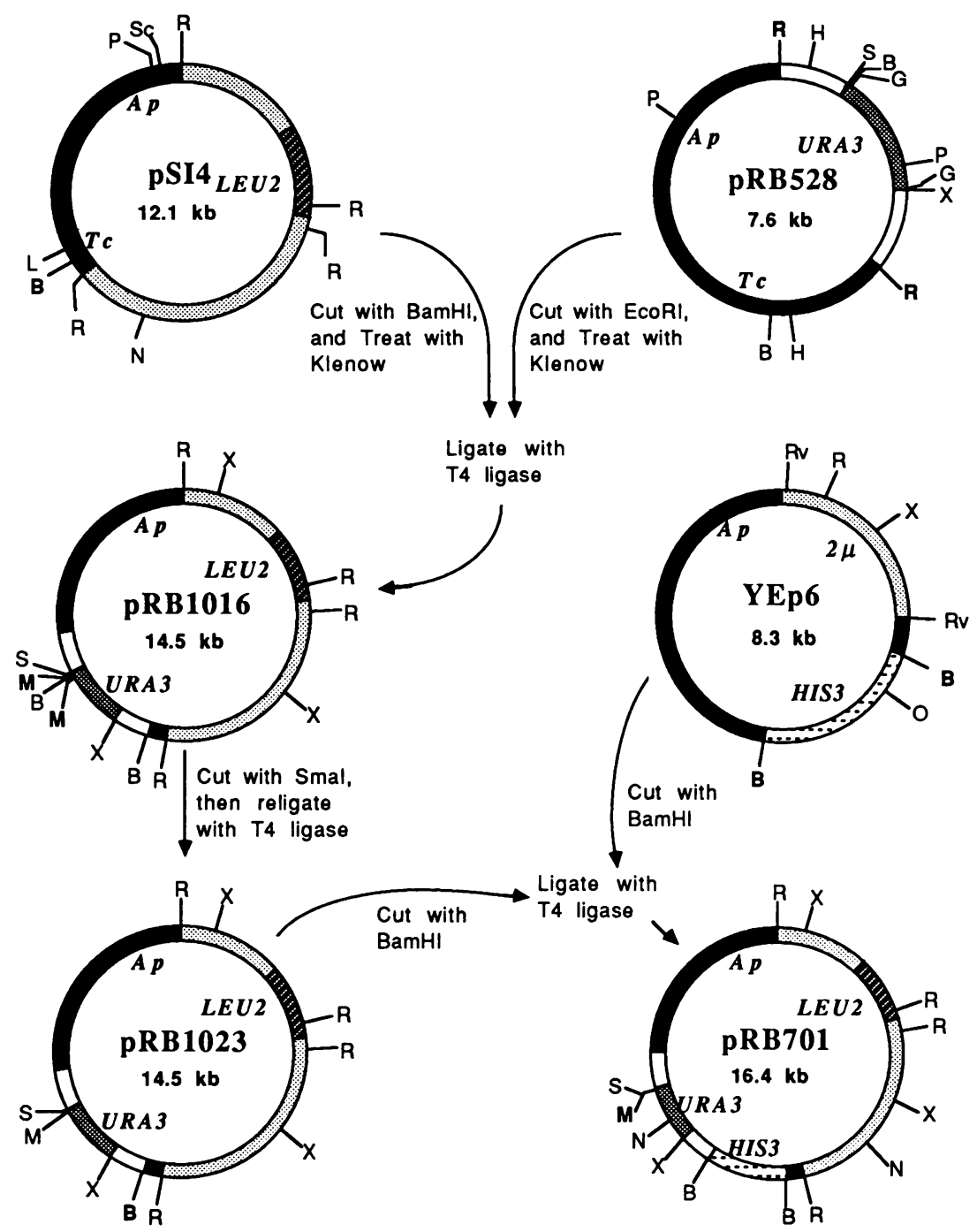

FIG. 3. Construction of pRB701. Plasmid pRB701 was made in the following steps. (i) pSI4 was cut with BamHI and then treated with Klenow fragment of $E$. coli DNA polymerase I, followed by ligation with Klenow-treated EcoRI fragment of the HXK2::URA3 disruption from pRB528. (ii) One of the products (pRB1016) was unexpectedly found to have retained a BamHI site at the new joint proximal to the $E c o$ RI site in the pBR322 sequence; pRB1016 has another BamHI site between two SmaI sites at one of the junctions of the HXK2 and URA3 sequences. (iii) pRB1016 was cut with $S m a I$ and then religated to remove that BamHI site. (iv) A 1.8-kb BamHI fragment of the HIS3 gene from YEp6 was ligated into the remaining BamHI site at the junction of the $H X K 2$ and pBR322 sequences. Symbols: , pBR322 sequences; $\square, 5^{\prime}$ - and 3'-flanking sequences of the $H X K 2$ gene; rita , $2 \mu \mathrm{m}$ sequences. Other regions are as labeled. Abbreviations for enzymes: B, BamHI; G, BglII; H, HindIII; L, SalI; M, SmaI; N, NcoI; O, XhoI; P, PstI; R, EcoRI, Rv, EcoRV; S, SacI; Sc, ScaI; X, XbaI.

presence of glucose. A yeast strain (DBY2230) with null alleles $h x k 1:: L E U 2, h x k 2-202$, gallo-120, and ura3-52 was transformed with combinations of deletion fragments and linearized plasmids containing $h x k 2$ point mutations; $\mathrm{Ura}^{+}$ transformants were replica plated onto plates containing $2 \%$ glucose and $2 \%$ galactose. The wild-type recombinants were able to repress $G A L 1$ expression and were spared from galactose killing, whereas mutants failed to repress $G A L I$ and could not grow.

Enzyme assays. For hexokinase and invertase assays, cells were grown in medium containing $5 \%$ glucose, fructose, or mannose and harvested in the mid-exponential phase (optical density at $600 \mathrm{~nm}$ of 1.0 to 2.0). Invertase activity was measured as described by Goldstein and Lampen (30) on whole cells collected from mid-exponential-phase cultures. Hexokinase activity was assayed on crude extracts from mid-exponential-phase cells essentially as described previ- ously (10), with slight modifications (46). Protein concentration was determined by the method of Lowry et al. (45).

Western blots (immunoblots). To screen for full-length inactive mutant proteins, yeast cells containing plasmids carrying $h x k 2$ mutations incapable of supporting growth on fructose were grown overnight in medium selecting for the plasmid and harvested. The cells were boiled in sodium dodecyl sulfate-containing protein gel sample buffer before lysis with glass bead beating. The crude extracts were used in Western blot (15) analysis with rabbit antihexokinase antiserum.

\section{RESULTS AND DISCUSSION}

The idea behind our approach to the study of hexokinase II is to obtain mutants with interesting phenotypes without making any prior assumptions about the amino acid residues 
responsible for hexokinase II function, whether catalytic in glucose phosphorylation or regulatory in glucose repression. Plasmid-borne copies of the $H X K 2$ gene were mutated at random, and the DNA pools from the mutagenesis were used to transform yeast cells. The yeast transformants were screened for interesting phenotypes on a range of carbon sources and under several repressing conditions. The locations of the mutations were determined by fine-structure mapping, and many of the mutants were sequenced. Additional phenotypic analyses were performed to further characterize the mutants, and an attempt was made to understand the properties of the mutants in relation to the positions of the altered amino acid residues in the crystal structure.

Mutagenesis. For the purpose of localized mutagenesis of the $H X K 2$ gene and for the convenience of later molecular manipulations, we chose to mutagenize a $H X K 2$ clone. The yeast centromere plasmids pRB312 and pRB313 were mutagenized as described in Materials and Methods. A total of 85,000 independent $E$. coli transformants with the mutagenized pRB312 were obtained by selection for ampicillin resistance; the transformants were combined into 32 pools of 500 to 3,500 transformants, and DNA was isolated from cultures of these pools. The mutation frequency was estimated as described in Materials and Methods. The frequency of Ura ${ }^{-}$ transformants was 2 to $3 \%$ among total $E$. coli transformants of the mutagenized plasmid. Assuming that the distribution of mutations is uniform throughout the plasmid, we estimate the mutation frequency for $H X K 2$ to be about $5 \%$, because the $H X K 2$ gene is twice as large as URA3.

Both mutagenesis methods used produced, among the 35 mutants ultimately sequenced, 30 single changes, 4 double mutants, and 1 triple mutant. Of the mutations generated in an $E$. coli mutD strain, 12 are transitions and 7 are transversions, a nonspecificity consistent with previous observations $(18,19,26)$. Among the mutations generated by the misincorporation method, two-thirds are single-base changes and one-third contain two or more base changes per allele.

Screening for mutant phenotypes. Yeast cells transformed with mutagenized pRB313 or pRB312 were screened for various phenotypes. One screening method was for the loss or decrease of hexokinase catalytic activity. In cells of the $h x k l h x k 2$ null background, the only hexokinase is encoded by the plasmid; sufficient reduction of the plasmid-encoded hexokinase activity due to a mutation can lead to a deficiency in fructose fermentation, which requires the activity of hexokinase. In the first experiment, mutagenized pRB313 DNAs isolated from independent cultures of an $E$. coli mutD strain were used to transform yeast strain DBY2052, and the transformants were replica plated to fructose plates. Those transformants that grew as poorly on fructose as did the double-null $h x k l h x k 2$ mutant were picked as mutants; 18,000 transformants were screened, and eight mutant candidates were identified. The same type of screen was performed by using pRB312 DNA mutagenized by misincorporation, and nine mutant candidates were identified when 1,700 transformants of DBY2192 were screened.

To obtain mutants that had defects in glucose repression but still retained high levels of hexokinase activity, transformants of DBY2052 with pRB313 DNA were pooled, and mutants were identified by using medium containing $2 \%$ raffinose and $0.02 \%$ 2-deoxyglucose. After a 1-week incubation at $30^{\circ} \mathrm{C}$, colonies were picked as mutant candidates. The mutant candidates were then rechecked for growth phenotype on fructose. From the screen of $23,000(18,000$ from the procedure described above plus 5,000 more) transformants,
55 mutant candidates were identified. Because more than one mutant was picked from among the yeast transformants of a single $E$. coli DNA preparation, the transformants are not independent. In a second trial of the same screen, mutagenized pRB312 DNA was used to transform DBY2052. Another 18,000 transformants were replica plated on glucose and incubated at $30^{\circ} \mathrm{C}$ for $8 \mathrm{~h}$. The transformants were then replica plated on $2 \%$ raffinose and $0.02 \% 2$-deoxyglucose as before. A total of about $\mathbf{4 0}$ candidates were picked, and two independent transformants were saved for further analysis after rechecking.

Another large screen sought to identify additional mutants with defects in fructose growth or glucose repression. Although glucosamine causes glucose repression and is phosphorylated, it is not used as a carbon source. For a wild-type strain, growth is inhibited on raffinose or galactose plus glucosamine, since synthesis of the enzymes required to utilize raffinose or galactose cannot be derepressed. Transformants with mutagenized pRB312 DNA were replica plated on raffinose or galactose in the presence and absence of the glucosamine and on fructose. A total of 30,000 transformants of DBY2192 was screened for mutant phenotypes. A large number of candidates were chosen, purified, and retested; 328 that retained their original phenotypes were saved. The mutants that retested cleanly were defective for growth on fructose; the repression defects were less extreme and more difficult to score.

If hexokinase II is involved in the signaling of glucose repression, then there might be mutations that cause the enzyme to send repressing signaling even in the absence of glucose. Specifically, there should be mutants of hexokinase II that fail to use one or more of the glucose repressionsensitive carbon sources, such as sucrose, galactose, or raffinose. Six mutant candidates were found when the aforementioned 1,700 transformants of DBY2192 were screened on galactose.

Among the different methods used for screening $h x k 2$ mutants, growth on fructose is a simple assay that yielded a large number of mutants exhibiting a wide range of phenotypes. The other screens are relatively complicated and allowed the isolation of mutants with partial activity. Specifically, the selection using raffinose and 2-deoxyglucose, designed to detect mutants with high catalytic activity but little glucose repression, did not perform as well as we had hoped. None of the isolated mutants had wild-type-level hexokinase activity, and some mutants with extremely low activity also survived the selection. The screens for glucose repression-defective mutants by using glucosamine plus a carbon source such as galactose, and those for nonderepressing mutants by using glucose repression-sensitive carbon sources such as raffinose, also had limited success, since the phenotypes of the mutant candidates we recovered were not severe.

Fine-structure mapping of $h x k 2$ mutations. A representative subset of the mutants exhibiting a range of phenotypes was chosen for further analysis. Before making a more-detailed analysis of the mutant phenotypes, the mutations were localized to a specific region of the $H X K 2$ gene in the hope that the distribution of different kinds of mutations might suggest relationships between the structure and function of the protein. In the general case, mapping of mutations makes possible the distinction between a silent mutation uncovered by sequencing and one that causes the phenotype; furthermore, the labor involved in DNA sequencing is greatly reduced for mutations that have been mapped to small intervals, in our case about 100 base pairs. 


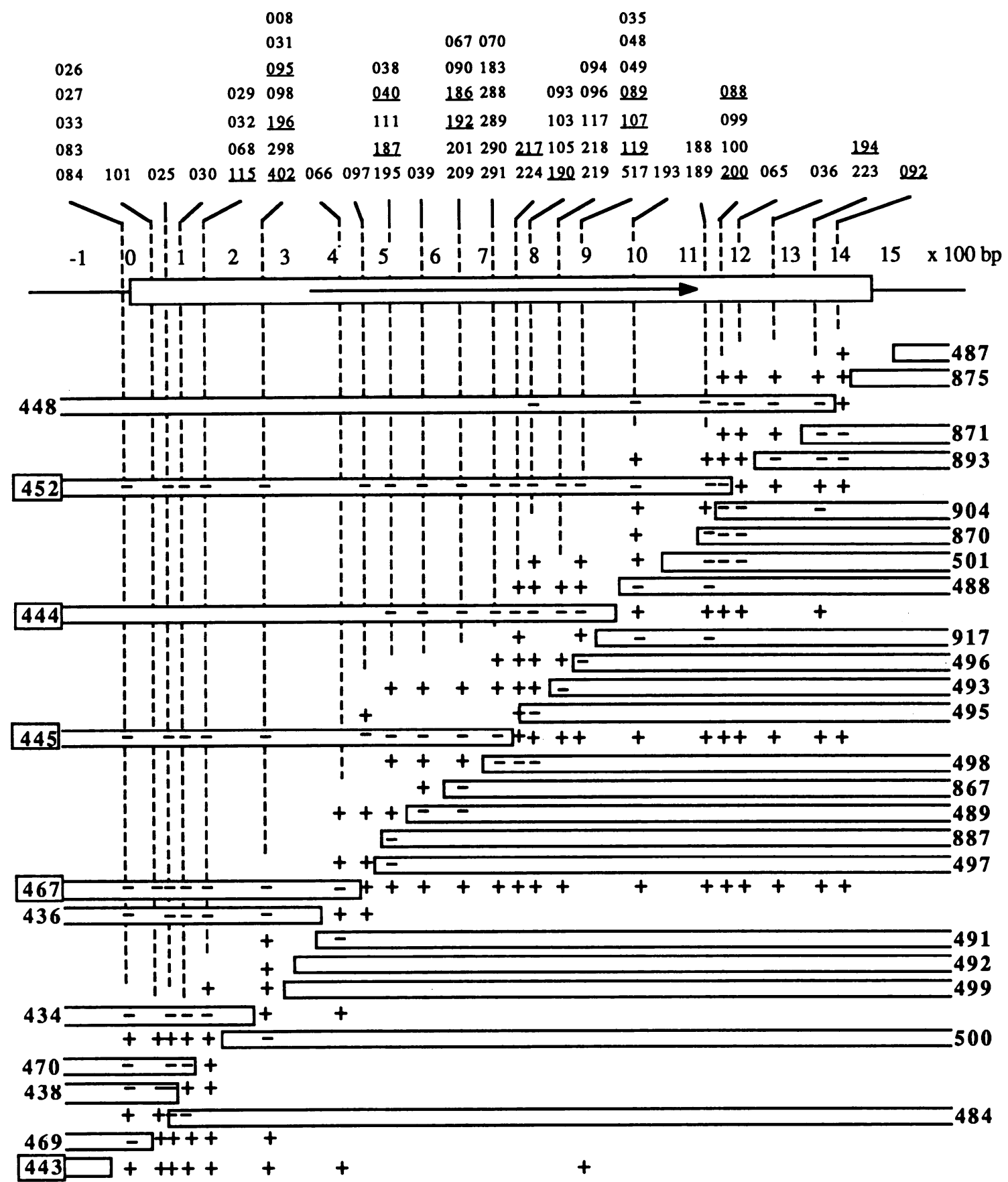

FIG. 4. Deletion map of $H X K 2$. The $H X K 2$ region shown includes the coding and some of the 5 ' and $3^{\prime}$ noncoding sequences, with the arrow indicating the direction of translation. The three-digit numbers of mutant alleles are positioned above their map intervals. The alleles that are underlined can support good growth on fructose; the other alleles cannot. The deletion fragments were generated from pRB309 derivatives, and the numbers either to their right or left designate the plasmids (pRB number); the deletions with a boxed number were used first to assign mutations into large intervals. Symbols: + , presence of wild-type recombinants; -, absence of such recombinants.

The mutations were mapped by using a simple and rapid method based on homologous recombination between transforming plasmid fragments in yeast cells (41). The results from many transformations with plasmids containing the point mutants and deletion fragments were used to generate a fine-structure map of the $H X K 2$ gene directly in yeast cells similar to the maps in procaryotes (Fig. 4), which shows that the mutations causing varying degrees of hexokinase defects are distributed throughout the gene without obvious cluster- ing of any particular type of mutation. This is not surprising, because the three-dimensional structure indicates that the protein cannot simply be separated into domains at the level of primary structure.

Growth phenotypes of wild type, null mutants, and point mutants. Growth of the null and wild-type strains was examined as standards for comparing the behavior of the point mutants. As discussed above, hexokinase II is involved in several processes of cellular metabolism. Although 
TABLE 2. Growth rates of wild type and hexokinase null mutants in different glucose-containing media

\begin{tabular}{|c|c|c|c|c|c|}
\hline \multirow{2}{*}{$\begin{array}{l}\text { DBY } \\
\text { strain }\end{array}$} & \multicolumn{2}{|c|}{ Genotype $^{a}$} & \multicolumn{3}{|c|}{ Mean doubling time $(\mathrm{h}) \pm \mathrm{SE}^{b}(\%)^{c}$} \\
\hline & $\overline{h x k 1}$ & $h \times k 2$ & YPD & SD CAS & SD \\
\hline 1315 & + & + & $1.72 \pm 0.05(100)$ & $2.21 \pm 0.02(100)$ & $3.01 \pm 0.04(100)$ \\
\hline 2053 & - & + & $1.73 \pm 0.01(101)$ & $2.19 \pm 0.02(99)$ & $3.04 \pm 0.07(101)$ \\
\hline 2184 & + & - & $2.03 \pm 0.02$ & $2.58 \pm 0.04$ & $4.59 \pm 0.15(152)$ \\
\hline 2052 & - & - & $2.54 \pm 0.03(148)$ & $3.21 \pm 0.07(145)$ & $4.68 \pm 0.06(155)$ \\
\hline
\end{tabular}

${ }^{a} h x k 1, h x k 1:: L E U 2 ; h x k 2, h x k 2-202$.

${ }^{b}$ Calculated from linear regression of data. Growth media: YPD, YEP plus $2 \%$ glucose; SD CAS, SD with $0.2 \%$ Casamino Acids.

c Percentage of wild-type doubling time on the same medium.

cells can grow on glucose without hexokinase (because of the presence of glucokinase), the double mutant grows more slowly than does the wild type (44). This phenotype was examined more quantitatively with null mutants of the $H X K 1$ and $H X K 2$ genes. Wild-type cells, $h x k 1$ or $h x k 2$ single mutants, and the double mutant were grown in the yeast rich medium YEP glucose, the minimal medium SD with auxotrophic requirements, and SD supplemented with Casamino Acids (Difco Laboratories, Detroit, Mich.). Growth was monitored by periodic determination of cell density; the doubling times are shown in Table 2. The $h x k 1$ mutant behaved like the wild type in all three media. On poorer media, the phenotype of the $h x k 2$ mutant approached that of the double null, which had doubling times $50 \%$ longer than wild-type values. Because all biosynthetic precursors must ultimately be generated from glucose in the absence of rich nutrients, the glucose-phosphorylating activity probably becomes limiting for cell growth. During growth on glucose, the hexokinase activity in yeast cells is predominantly from hexokinase II (52); this may explain, at least in part, why the $h x k l$ mutation has no effect, whereas in minimal medium the $h x k 2$ mutation reduces the growth rate as much as do both mutations.

A subset of the point mutants was examined quantitatively with respect to growth on glucose. These cells have the chromosomal null mutations in both hexokinase genes and carry plasmids expressing mutant hexokinase II. The mutants exhibited a range of doubling times on glucose and various levels of growth on fructose (Table 3). Furthermore, the mutants that failed to grow on fructose plates also had longer doubling times on glucose, whereas those that grew fairly well on fructose had doubling times on glucose close to that of wild type. The results suggest that the hexokinase II defects affect catalytic activity with either glucose or fructose as the substrate.

Invertase activity of hxk2 point mutants. Invertase activity was measured for several $h x k 2$ point mutants to determine the extent of glucose repression. Invertase is a good indicator of glucose repression because invertase production is normally repressed several hundredfold in the presence of glucose and other repressing substrates and because the enzyme can be easily assayed. The mutants that failed to grow on fructose had high levels of invertase activity; those with short doubling times on glucose grew relatively well on fructose and had low levels of invertase (Table 3 ). The behavior of the mutants suggested an inverse correlation between hexokinase II catalytic activity and the level of glucose repression. The correlation is examined more thoroughly in the accompanying paper (46).

Hexokinase activity of $h x k 2$ point mutants. In the chromosomally double null strains used in this study, the plasmidborne hexokinase II gene provides the only source of activity capable of supporting growth on fructose or mannose as the carbon source. Therefore, the growth phenotypes of the mutants on these sugars should give some indication of the in vivo catalytic activity of the altered hexokinase II. We anticipated that a class of mutants with a temperaturesensitive phenotype for growth on carbon sources with different kinetic parameters as hexokinase substrates might be particularly informative about the mechanism of catalysis. To identify temperature-sensitive mutants, we examined about 100 mutants identified in early screening rounds as defective in catalysis or repression, using plate growth assays on either fructose or mannose at 37,26 , or $14^{\circ} \mathrm{C}$. A large number of mutants failed to grow on both sugars at any temperature (data not shown); many of these were originally isolated on the basis of their failure to grow at $30^{\circ} \mathrm{C}$ on fructose plates. Another group of mutants showed lower

TABLE 3. Phenotypes of $h x k 2$ point mutants

\begin{tabular}{|c|c|c|c|c|}
\hline \multirow{2}{*}{$\begin{array}{l}h x k 2 \\
\text { allele }^{a}\end{array}$} & \multicolumn{2}{|c|}{$\begin{array}{l}\text { Doubling time (fold) } \\
\text { (h) on glucose } \mathrm{e}^{b}\end{array}$} & \multirow{2}{*}{$\begin{array}{l}\text { Growth on } \\
\text { fructose } \\
\text { plates }^{c}\end{array}$} & \multirow{2}{*}{$\begin{array}{l}\text { Invertase } \\
\text { activity }^{d}\end{array}$} \\
\hline & Expt 1 & Expt 2 & & \\
\hline$H X K 2$ (CEN) & 1.0 & 1.0 & +++ & 1.3 \\
\hline$H X K 2(2 \mu \mathrm{m})$ & 1.1 & 1.1 & +++ & \\
\hline$H X K l(2 \mu \mathrm{m})$ & 1.0 & & +++ & 19 \\
\hline 033 & 1.8 & & - & 100 \\
\hline 108 & 1.0 & & ++ & 2.1 \\
\hline 091 & 1.0 & 1.2 & ++ & 2.3 \\
\hline 109 & 1.1 & & +++ & 2.3 \\
\hline 082 & 1.0 & 1.2 & ++ & 2.4 \\
\hline 088 & 1.1 & & ++ & 4.0 \\
\hline 106 & 1.0 & & ++ & 5.0 \\
\hline 107 & 1.2 & & +++ & 5.0 \\
\hline 089 & 1.1 & & +++ & 7.0 \\
\hline 090 & 1.1 & & ++ & 15 \\
\hline 092 & 1.1 & & +++ & 20 \\
\hline 093 & 1.1 & 1.2 & ++ & 10 \\
\hline 085 & 1.1 & 1.2 & ++ & 24 \\
\hline 110 & 1.2 & & ++ & 19 \\
\hline 036 & 1.3 & & ++ & 20 \\
\hline 040 & 1.1 & & ++ & 23 \\
\hline 087 & 1.2 & 1.4 & ++ & 42 \\
\hline 048 & 1.7 & & + & 54 \\
\hline 084 & 1.6 & & - & 76 \\
\hline 086 & 1.4 & 1.7 & - & 76 \\
\hline 038 & 1.6 & & - & 88 \\
\hline 049 & 1.7 & & - & 89 \\
\hline 083 & 1.5 & 1.7 & - & 93 \\
\hline 039 & 1.6 & & - & 95 \\
\hline 035 & 1.6 & & - & 99 \\
\hline
\end{tabular}

a The wild-type $H X K 1$ or $H X K 2$ alleles are indicated; the others are $h \times k 2$ alleles, all in a $h x k l h x k 2$ double chromosomal null mutation strain. CEN, Centromere plasmid.

${ }^{b}$ Expressed relative to the wild-type $H X K 2$ value on a centromere plasmid.

c Symbols represent a crude estimate of the degree of growth on fructose.

${ }^{d}$ Expressed as percentage of the null mutant value, which was considered 100 . 
TABLE 4. $h x k 2$ mutants that are temperature sensitive for growth on fructose

\begin{tabular}{|c|c|c|c|c|c|c|}
\hline \multirow{2}{*}{$\begin{array}{c}h x k 2 \\
\text { allele(s) }\end{array}$} & \multicolumn{2}{|c|}{$\begin{array}{l}\text { Growth on } \\
\text { fructose }^{a}\end{array}$} & \multicolumn{2}{|c|}{$\begin{array}{l}\text { Hexokinase } \\
\text { activity }(\mathrm{U})^{b}\end{array}$} & \multirow{2}{*}{$\begin{array}{l}\text { Amino acid } \\
\text { alteration }^{c}\end{array}$} & \multirow{2}{*}{$\begin{array}{l}\text { Three-dimensiona } \\
\text { structure }^{d}\end{array}$} \\
\hline & $26^{\circ} \mathrm{C}$ & $37^{\circ} \mathrm{C}$ & $26^{\circ} \mathrm{C}$ & $37^{\circ} \mathrm{C}$ & & \\
\hline Wild type & ++ & + & 3.1 & 2.5 & & \\
\hline 115 & ++ & $+1-$ & 0.3 & 0.1 & Gly-55 $\rightarrow$ Asp & $\alpha$ helix \\
\hline 094 & ++ & $+1-$ & 0.2 & 0.03 & Asp-286 $\rightarrow$ Val & $\alpha$ helix \\
\hline 195 & ++ & $+1-$ & 1.2 & 0.6 & Gln-163 $\rightarrow$ Arg & $\beta$ sheet \\
\hline 187 & + & - & 0.2 & 0.1 & $\begin{array}{l}\text { Ile- } 180 \rightarrow \text { Leu } \\
\text { Asn- } 182 \rightarrow \text { Asp }\end{array}$ & \\
\hline 192 & + & - & 0.1 & 0.06 & Gln-193 $\rightarrow$ Pro & $\alpha$ helix \\
\hline 186 & + & - & 0.1 & 0.2 & Leu-216 $\rightarrow \operatorname{Trp}$ & $\alpha$ helix \\
\hline 217 & + & - & 0.7 & 0.5 & Ala-239 $\rightarrow$ Thr & $\beta$ sheet \\
\hline 224 & + & - & 0.4 & 0.2 & Ala-239 $\rightarrow$ Val & $\beta$ sheet \\
\hline 117 & + & - & 0.7 & 0.1 & Asp-286 $\rightarrow$ Gly & $\alpha$ helix \\
\hline 218 & + & - & 1.2 & 0.4 & Asp-286 $\rightarrow$ Leu & $\alpha$ helix \\
\hline $089,107,119$ & ++ & - & 0.5 & 0.1 & Ser-305 $\rightarrow$ Pro & \\
\hline 193 & + & - & 0.3 & 0.2 & $\begin{array}{l}\text { Met-321 } \rightarrow \text { Arg } \\
\text { Ser-322 } \rightarrow \text { Ala }\end{array}$ & $\begin{array}{l}\alpha \text { helix } \\
\alpha \text { helix }\end{array}$ \\
\hline 088 & ++ & - & 0.8 & 0.2 & $\begin{array}{l}\text { Gln-376 } \rightarrow \text { Glu } \\
\text { Arg-391 } \rightarrow \text { Gly }\end{array}$ & $\begin{array}{l}\alpha \text { helix } \\
\alpha \text { helix }\end{array}$ \\
\hline 200 & ++ & $+1-$ & 0.8 & 0.3 & Arg-391 $\rightarrow$ Ser & $\alpha$ helix \\
\hline
\end{tabular}

${ }^{a}$ Levels of growth: ++ , wild type; - , null mutant.

${ }^{b}$ Assays were performed with extracts from cells grown on glucose at the indicated temperatures. One unit $=1 \mu$ mol of fructose phosphorylated min ${ }^{-1}\left(\mathrm{mg}^{\circ}\right.$ of total protein $)^{-1}$. Both sets of extracts were prepared in the cold in the presence of phenylmethylsulfonyl flouride.

${ }^{c}$ Deduced from the DNA sequence of the mutations.

${ }^{d}$ From the refined three-dimensional structures of the isoenzymes (Harrison, Ph.D. dissertation, 1985).

growth on fructose at $37^{\circ} \mathrm{C}$ than at $26^{\circ} \mathrm{C}$ (Table 4); they had shown partial growth on fructose at $30^{\circ} \mathrm{C}$ in the original screen. The mutants that exhibited reduced growth on fructose at $37^{\circ} \mathrm{C}$ showed similar extents of growth on mannose at either 26 or $37^{\circ} \mathrm{C}$ (data not shown), which means that these mutants have a differential temperature-sensitive growth phenotype for the substrates fructose and mannose.

The mutants that were temperature sensitive for growth on fructose were analyzed in vitro. Crude extracts made from these mutants generally had low levels of hexokinase activity (Table 4). In addition, hexokinase activity in many mutants was lower in crude extracts from the cells grown on glucose at $37^{\circ} \mathrm{C}$ than at $26^{\circ} \mathrm{C}$, whereas extract from the wild-type cells showed only a slight drop in activity.

The largest class of mutants were the totally inactive ones, as judged by their failure to grow on fructose. Many of these mutants probably resulted from frameshift or nonsense mutations or they may produce proteins that are sensitive to protease degradation. Nevertheless, we reasoned that a subset of these mutants may produce proteins that are catalytically inactive but still relatively stable; among these there should be mutations that specifically alter amino acid residues responsible for catalysis without changing the overall structure of the protein. Therefore, the members of this class of mutants were examined for the production of intact yet inactive hexokinase II protein. Western blot experiments were performed on about $\mathbf{1 4 0}$ mutants that grew as poorly on fructose as did the double-null mutant. Only six mutants were found to contain intact protein by this assay; most mutants had no detectable intact hexokinase II activity (Fig. 5).

Sequences of the mutations. Many of the mutations identified during the phenotypic screens were sequenced after they were mapped (5). We were interested in finding out the positions of the three-dimensional structure, as determined by X-ray crystallography, of the amino acid residues altered in the mutants temperature sensitive for growth on fructose. Sequence analysis of these mutants (Table 4) showed that many of the changes were in the middle of an $\alpha$ helix or $\beta$ sheet. In addition, some mutations changed residues (e.g., Gln-193 and Ser-305) to prolines. Examination of the threedimensional structure of hexokinase II indicated that almost all of these mutations altered residues that are relatively far from the sugar-binding site. Many of the amino acid residues that were altered by the fructose-temperature-sensitive mutations were seen to be partially or completely buried inside the protein. Studies with lambda repressor $(35,36,54)$ and T4 lysozyme $(1-3,31-33)$ indicate that alterations in the interior of the protein tend to cause thermal instability, whereas mutations on the protein surface have much less effect on stability. In addition, most of these mutant hexokinase II proteins are found in the cell at much lower levels than is the wild-type enzyme. Studies of the Cro protein

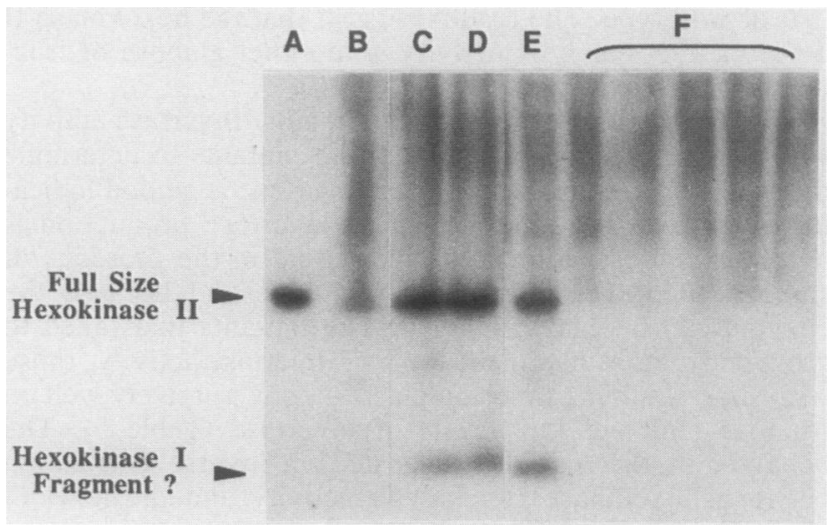

FIG. 5. Autoradiogram of Western blot screening for intact inactive hexokinase II. Lanes: A, wild type; B, hxk2-298 (Gly$89 \rightarrow$ Asp); C, $h x k 2-289 ; \mathrm{D}, h x k 2-290$ (C and D, Asn-237 $\rightarrow$ His); E, $h x k 2-049$ (Ser-306 $\rightarrow$ Phe); F, examples of mutants with no detectable hexokinase II. The lower band in some lanes could be the hexokinase I fragment made from the $h x k 1:: L E U 2$ disruption. 


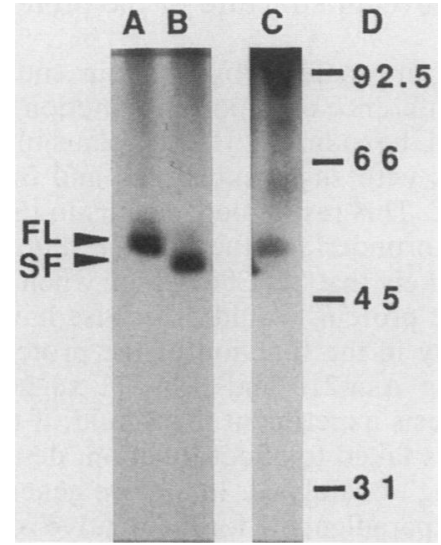

FIG. 6. Autoradiogram of Western blot for the ATG mutant. Lanes: A, wild type; B, N-terminal deletion form, lacking first 15 amino acid residues; $C$, the ATG mutant; D, size standards. Lanes $A$ and $B$ are from a 5-h exposure, and lane $C$ is from an 18-h exposure. All three lanes are from the same gel and filter. The mutant hexokinase II is the same size as full-length (FL) hexokinase II. The short form (SF) of the enzyme lacks the first 15 amino acids.

mutants (56) of lambda bacteriophage showed that a large number of mutations cause increased sensitivity to protease. Because the sequences controlling transcription and translation initiation of $H X K 2$ were not altered in these mutants, it is possible that they are present at low steady-state levels due to increased degradation. A significant fraction of the proteins were present at such low levels that reduced growth at $37^{\circ} \mathrm{C}$ relative to growth at $26^{\circ} \mathrm{C}$ could be explained if the amount of hexokinase activity were more rate limiting at the higher temperature.

A mutation in the initiation codon. The mapping results also uncovered an interesting mutant that grew poorly on fructose and failed to grow on mannose. The mutant allele, $h x k 2-083$, maps to the very beginning of the $H X K 2$ gene; sequence analysis indicates that it alters the initiation codon from ATG to ATA. A Western blot experiment showed that the mutant allele produced a protein that was approximately of wild-type size (Fig. 6) but in much lower amounts than the wild-type level.

To further characterize this mutant enzyme, the $h x k 2-083$ mutation was transferred to two kinds of multicopy plasmids: YEp420 and pSI4 derivatives (15 to 40 and 100 to 200 copies per cell, respectively; see Materials and Methods).
Yeast cells containing different copy numbers of wild-type or $h x k 2-083$ alleles were analyzed for growth on hexoses and for glucose repression. The protein from $h x k 2-083$ could provide enough hexokinase II activity for growth on fructose if it were overproduced from a YEp420 derivative (Table 5). It could also allow growth on mannose and provide glucose repression if it were produced at a much higher level from a pSI4 derivative. The hexokinase activity from a strain with such a pSI4 derivative, using fructose as a substrate, was about the same as from cells with a centromere plasmid carrying a $H X K 2$ allele. We suggest that the ATG is necessary for efficient expression but not for encoding catalytic activity of hexokinase II.

Structure-function correlations. The six mutant isolates identified by Western blot analysis as producing full-length hexokinase II proteins incapable of supporting growth on fructose were analyzed by DNA sequencing after they had been mapped. They altered three different amino acid residues (Table 6): Gly-89 $\rightarrow$ Asp ( $h x k 2-298)$, Asn-237 $\rightarrow$ His (hxk2-183, -289, and -290), and Ser-306 $\rightarrow$ Phe ( $h x k 2-049$ and -517). In addition to these three mutations uncovered by Western blot analysis, sequence analysis of other null-like mutations, which were found by screening on fructose plates, identified three other missense mutations (Table 6): Thr-90 $\rightarrow$ Ile $(h x k 2-098)$ and Gly-235 $\rightarrow$ Cys $(h x k 2-070)$ and a mutation (hxk2-065) changing two residues, Gln-376 $\rightarrow$ Glu and Ile-381 $\rightarrow$ Met. Among the altered amino acid residues, Gly-235 and Asn-237 have been proposed to form hydrogen bonds with the glucose analog $O$-toluoylglucosamine (Harrison, Ph.D. dissertation, 1985). The other residues affected by the mutations we have identified are not thought to be within hydrogen-bonding distance of the sugar substrate analog.

The amino acid residues involved in these mutations are logically good candidates for mutations that simply affect the function of the protein, as opposed to its synthesis or stability. Probable effects of the mutations might be to impair catalysis or substrate binding. On the basis of the crystal structure (Harrison, Ph.D. dissertation, 1985) of hexokinase II complexed with the glucose analog $O$-toluoylglucosamine, only two of these residues (Gly-235 and Asn-237) can potentially form hydrogen bonds with the sugar substrate. However, the role of Gly-235 and Asn-237 is not entirely clear: the structure of the closed form of hexokinase I complexed with glucose suggests that Asn-210 and Asp-211 are more likely to form hydrogen bonds with sugars than are Gly-235 and Asn-237. The reason for this apparent disagreement may be due to differences in interpretation of structures at

TABLE 5. Analysis of the ATG mutant

\begin{tabular}{|c|c|c|c|c|c|c|}
\hline \multirow{2}{*}{$\begin{array}{c}\text { Type of } \\
\text { plasmid }^{a}\end{array}$} & \multirow{2}{*}{$\begin{array}{l}h \times k 2 \\
\text { allele }\end{array}$} & \multicolumn{2}{|c|}{ Activity (U) } & \multicolumn{3}{|c|}{ Doubling time $(\min )$ on: } \\
\hline & & Hexokinase $^{b}$ & Invertase $^{c}$ & Glucose & Fructose & Mannose \\
\hline CEN & Wild type & 2.4 & 3.0 & 120 & 124 & 175 \\
\hline CEN & 083 & 0.2 & 87 & 220 & $>1,500$ & $>1,500$ \\
\hline $2 \mu \mathrm{m}$ & 083 & $\mathrm{NT}^{d}$ & NT & 150 & 175 & $>1,500$ \\
\hline $2 \mu \mathrm{m}$ leu 2 & 083 & 2.7 & 1.5 & $360^{e}$ & $400^{e}$ & $470^{e}$ \\
\hline CEN & None & 0 & 85 & 315 & $\mathrm{NG}^{f}$ & NG \\
\hline
\end{tabular}

${ }^{a}$ The $2 \mu \mathrm{m}$ leu2 plasmid is a derivative of pSI4 (14) that carries an allele of the $L E U 2$ gene believed to be inefficiently transcribed; therefore, selection for Leu ${ }^{+}$ leads to high copy number of the plasmid. The approximate copy numbers are: CEN (centromere plasmid), 1 to $5 ; 2 \mu \mathrm{m} 15$ to $40 ; 2 \mu \mathrm{m}$ leu2, 100 to 200 .

${ }_{b}^{b}$ Cells were grown on glucose, and activity was assayed with fructose as the substrate. One unit $=1 \mu \mathrm{mol}$ of fructose phosphorylated $\mathrm{min}^{-1}$ (mg of total protein) ${ }^{-1}$.

c Cells were grown on $5 \%$ glucose. One unit $=1 \mu \mathrm{g}$ of glucose produced $\min ^{-1}(\mathrm{ml} \text { of cells at optical density at } 600 \mathrm{~nm} \text { of } 1)^{-1}$.

${ }^{d}$ NT, Not tested.

e Doubling time was much longer because of the inefficient LEU2 allele; cells with the HXK2 allele on the same kind of plasmid also grew very slowly.

$f$ NG, No growth. 
TABLE 6. Sequenced $h x k 2$ mutations and the corresponding mutant phenotypes

\begin{tabular}{|c|c|c|c|}
\hline \multicolumn{2}{|c|}{$\begin{array}{l}\text { Screening phenotype }{ }^{a} \\
\text { for growth on: }\end{array}$} & \multirow{2}{*}{$h x k 2$ allele } & \multirow{2}{*}{$\begin{array}{l}\text { Amino acid } \\
\text { alteration(s) }\end{array}$} \\
\hline Fructose & $2-\mathrm{dGlc}^{b}$ & & \\
\hline+ & $+1-$ & 040 & Phe-178 $\rightarrow$ Ile \\
\hline- & $+1-$ & $049,517^{c, d}$ & Ser $-306 \rightarrow$ Phe \\
\hline- & + & $065^{e}$ & Gln-376 $\rightarrow$ Glu, Ile-381 $\rightarrow$ Met \\
\hline - & + & $070^{e}$ & Gly-235 $\rightarrow$ Cys \\
\hline$+1-$ & + & 083 & Met- $1 \rightarrow$ Ile \\
\hline$+1-$ & + & 088 & Gln-376 $\rightarrow$ Glu \\
\hline+ & + & $089,107,119$ & Ser-305 $\rightarrow$ Pro \\
\hline$+1-$ & + & 090 & Leu-216 $\rightarrow$ Ser \\
\hline$+1-$ & + & 093 & Leu-250 $\rightarrow$ Pro \\
\hline$+1-$ & + & $094,096^{e}$ & Asp-286 $\rightarrow$ Val \\
\hline+ & + & 095 & Glu-78 $\rightarrow$ Cys \\
\hline- & NT & $098^{d}$ & Thr-90 $\rightarrow$ Ile \\
\hline$-1+$ & NT & $103,105^{c}$ & Leu-250 $\rightarrow$ Pro \\
\hline$+1-$ & + & 111 & Ala-161 $\rightarrow$ Asp \\
\hline+ & + & 115 & Gly-55 $\rightarrow$ Asp \\
\hline$+1-$ & + & 117 & Asp- $286 \rightarrow$ Gly \\
\hline$-(\mathrm{ts}),+1-$ & NT & $183,289,290^{c, d}$ & Asn-237 $\rightarrow$ His \\
\hline & NT & 186 & Leu-216 $\rightarrow$ Trp \\
\hline$+/-(\mathrm{ts}),+$ & NT & 187 & Ile- $180 \rightarrow$ Leu, Asn- $182 \rightarrow$ Asp \\
\hline$-(\mathrm{ts}),+/-$ & NT & 188 & $\begin{array}{l}\text { Arg- } 382 \rightarrow \text { Thr, Arg-383 } \rightarrow \text { Pro, } \\
\text { Glu- } 386 \rightarrow \text { Gln }\end{array}$ \\
\hline+ & NT & 192 & Glu-193 $\rightarrow$ Pro \\
\hline$+1-$ & NT & 193 & Met-321 $\rightarrow$ Arg, Ser-322 $\rightarrow$ Ala \\
\hline+ & NT & 194 & Leu-435 $\rightarrow$ Ser \\
\hline$+/-(\mathrm{ts}),+$ & NT & 195 & Gln-163 $\rightarrow$ Arg \\
\hline+ & NT & 196 & Val-94 $\rightarrow$ Ala, Leu-99 $\rightarrow$ Trp \\
\hline$+/-(\mathrm{ts}),+$ & NT & 200 & Arg-391 $\rightarrow$ Ser \\
\hline$+/-(\mathrm{ts}),+$ & NT & 201 & Tyr-220 $\rightarrow$ His \\
\hline+ & NT & 209 & Asn-210 $\rightarrow$ Ile \\
\hline+ & NT & 217 & Ala-239 $\rightarrow$ Thr \\
\hline$+1-$ & NT & 218 & Asp-286 $\rightarrow$ His \\
\hline$-(\mathrm{ts}),+1-$ & NT & 224 & Ala-239 $\rightarrow$ Val \\
\hline- & NT & $298^{e}$ & Gly-89 $\rightarrow$ Asp \\
\hline
\end{tabular}

${ }^{a}$ Levels of growth: + , wild type; -, double-null mutants (ts). The first phenotype indicated was scored at $37^{\circ} \mathrm{C}$, and the second phenotype was scored at $26^{\circ} \mathrm{C}$. NT, Not tested.

${ }^{b}$ Scored on plates containing $2 \%$ raffinose and $0.02 \%$ 2-deoxyglucose; growth implies a defect in glucose repression.

${ }^{c}$ Alleles in the same row are not independent.

${ }^{d}$ Cells with the indicated mutation(s) were shown to have an intact hexokinase II by Western blot.

${ }^{e}$ Alleles in the indicated group are independent.

different levels of resolution or to real differences in the structures of these two isoenzymes or it may represent aspects of the mechanism of sugar binding as yet not understood. Nevertheless, regardless of the role of Gly-235 and Asn-237 in hydrogen bonding to a sugar substrate, the substitution of glycine with cysteine and that of asparagine with histidine could disrupt sugar binding simply because of the positions of the residues.

The residue Gly-89 lies at the end of an antiparallel beta loop in the domain that moves during the conformation change upon glucose binding. The fact that the mutation of this glycine to aspartate renders the enzyme inactive implies that the beta loop may be involved in the catalysis after the conformation change. The substitution of Phe for Ser-306 may affect activity by disrupting the active-site structure with the introduction of a large side chain. Finally, the substitutions Gln-376 to Glu and Ile-381 to Met may represent leads to the mechanisms of the function of the protein that are not obvious from the crystallographic information. On the other hand, the possibility remains that these muta- tions affect the overall structure of the protein rather than the active site.

Conclusion. Our analysis by random mutagenesis has resulted in the inference of important function for two amino acid residues of hexokinase II that plausibly might form hydrogen bonds with sugar substrates and four more residues that do not. This result alone seems to us to justify the effort required to undertake the random mutagenesis strategy, for it is unlikely that Ser-306, which when altered to Phe leads to inactive protein, would otherwise have been implicated specifically in the function of the protein. The ambiguity concerning Asn-210 and Asp-211 suggests a site-directed mutagenesis experiment that could, if the alterations of these residues failed to affect function, deny their role in substrate binding or catalysis. In a more general way, these results might be paradigmatic for the relative roles of random and site-directed mutagenesis in analysis of protein structure-function relationships; the random approach has the power to point to residues important for function, whereas the site-directed approach excels at experimental tests of preexisting hypotheses.

\section{ACKNOWLEDGMENTS}

We thank Mark Johnston and Andy Hoyt for the gifts of plasmids pSI4 and pRB331, respectively. We thank Bob Bourret for comments on the paper.

This research was supported by Public Health Service grant GM21253 from the National Institutes of Health, grant CDR850000003 from the National Science Foundation to D.B., and by Public Health Service grant GM20011 from the National Institutes of Health to C.T.W.

\section{LITERATURE CITED}

1. Alber, T., M. G. Grutter, T. M. Gray, J. A. Wozniak, L. H. Weaver, B.-L. Chen, E. N. Baker, and B. W. Matthews. 1986. Structure and stability of mutant lysozymes from bacteriophage T4. UCLA Symp. Mol. Cell. Biol. New Ser. 39:307-318.

2. Alber, T., D. Sun, J. A. Nye, D. C. Muchmore, and B. W. Matthews. 1987. Temperature-sensitive mutations of bacteriophage T4 lysozyme occur at sites with low mobility and low solvent accessibility in the folded protein. Biochemistry 26: 3754-3758.

3. Alber, T., D. Sun, K. Wilson, J. A. Wozniak, S. P. Cook, and B. W. Matthews. 1987. Contributions of hydrogen bonds of Thr 157 to the thermodynamic stability of phage T4 lysozyme. Nature (London) 330:41-46.

4. Anderson, C. M., R. C. McDonald, and T. A. Steitz. 1978. Sequencing a protein by X-ray crystallography. I. Interpretation of yeast hexokinase $\mathrm{B}$ at $2.5 \mathrm{~A}$ resolution by model building. $\mathrm{J}$. Mol. Biol. 123:1-13.

5. Anderson, C. M., R. E. Stenkamp, R. C. McDonald, and T. A. Steitz. 1978. A refined model of the sugar binding site of yeast hexokinase B. J. Mol. Biol. 123:207-219.

6. Anderson, C. M., R. E. Stenkamp, and T. A. Steitz. 1978. Sequencing a protein by X-ray crystallography. II. Refinement of yeast hexokinase B co-ordinates and sequence at $2.1 \mathrm{~A}$ resolution. J. Mol. Biol. 123:15-33.

7. Bennett, W. S., Jr., and T. A. Steitz. 1978. Glucose-induced conformational change in yeast hexokinase. Proc. Natl. Acad. Sci. USA 75:4848-4852.

8. Bennett, W. S., Jr., and T. A. Steitz. 1980. Structure of a complex between yeast hexokinase A and glucose. I. Structure determination and refinement at 3.5 A resolution. J. Mol. Biol. 140:183-209.

9. Bennett, W. S., Jr., and T. A. Steitz. 1980. Structure of a complex between yeast hexokinase A and glucose. II. Detailed comparison of conformation and active site configuration with the native hexokinase B monomer and dimer. J. Mol. Biol. 140:211-230.

10. Bergmeyer, H. U. (ed.). 1973. p. 473-474. Methods of enzymatic 
analysis, 2nd ed. Verlag Chemie, Weinheim, Federal Republic of Germany.

11. Borders, C. L., Jr., K. L. Cipollo, J. F. Jorkasky, and K. E. Neet. 1978. Role of arginyl residues in yeast hexokinase PII. Biochemistry 17:2654-2658.

12. Botstein, D., S. C. Falco, S. Stewart, M. Brennan, S. Sherer, D. Stinchcomb, K. Struhl, and R. W. Davis. 1979. Sterile host yeasts (SHY): a eukaryotic system of biological containment for recombinant DNA experiments. Gene 8:17-24.

13. Boyer, H. W., and D. Roulland-Dussoix. 1969. A complementation analysis of the restriction and modification of DNA in $E$. coli. J. Mol. Biol. 41:458-472.

14. Broach, J. R. 1983. Construction of high copy yeast vectors using 2- $\mu \mathrm{m}$ circle sequences. Methods Enzymol. 101:307-325.

15. Burnette, W. N. 1981. "Western blotting": electrophoretic transfer of proteins from sodium dodecyl sulfate-polyacrylamide gels to unmodified nitrocellulose and radiographic detection with antibody and radioiodinated protein A. Anal. Biochem. 112:195-203.

16. Carlson, M., B. C. Osmond, and D. Botstein. 1981. Mutants of yeast defective in sucrose utilization. Genetics 98:25-40.

17. Colowick, S. P. 1973. The hexokinases, p. 1-48. In P. D. Boyer (ed.), The enzymes, 3rd ed., vol. 9. Academic Press, Inc., New York.

18. Cox, E. C., and D.L. Horner. 1982. Dominant mutators in Escherichia coli. Genetics 100:7-18.

19. Degnen, G. E., and E. C. Cox. 1974. Conditional snutator gene in Escherichia coli: isolation, mapping and effector studies. J. Bacteriol. 117:477-487.

20. Derechin, M., A. Ramel, N. R. Lazarus, and E. A. Barnard. 1966. Yeast hexokinase. II. Molecular weight and dissociation behavior. Biochemistry 5:4017-4025.

21. Derechin, M., Y. M. Rustum, and E. A. Barnard. 1972. Dissociation of yeast hexokinase under the influence of substrate. Biochemistry 11:1793-1797.

22. Easterby, J. S., and M. A. Rosemeyer. 1972. Purification and subunit interactions of yeast hexokinase. Eur. J. Biochem. 28:241-252.

23. Entian, K.-D. 1980. Genetic and biochemical evidence for hexokinase PII as a key enzyme involved in catabolite repression in yeast. Mol. Gen. Genet. 178:633-637.

24. Entian, K.-D., and K.-U. Frohlich. 1984. Saccharomyces cerevisiae mutants provide evidence of hexokinase PII as a bifunctional enzyme with catalytic and regulatory domains for triggering catabolite repression. J. Bacteriol. 158:29-35.

25. Entian, K.-D., E. Kopetzki, K. U. Frohlich, and D. Mecke. 1984. Cloning of hexokinase isoenzyme PI from Saccharomyces cerevisiae: PI transformants confirm the unique role of hexokinase isoenzyme PII for glucose repression in yeast. Mol. Gen. Genet. 198:50-54

26. Fowler, R. G., G. E. Degnen, and E. C. Cox. 1974. Mutational specificity of a conditional Escherichia coli mutator, mutD5. Mol. Gen. Genet. 133:179-191.

27. Fraenkel, D. G. 1986. Mutants in glucose metabolism. Annu. Rev. Biochem. 55:317-337.

28. Frohlich, K.-U., K.-D. Entian, and D. Mecke. 1984. Cloning and restriction analysis of the hexokinase PII gene of the yeast Saccharomyces cerevisiae. Mol. Gen. Genet. 194:144-148.

29. Frohlich, K.-U., K.-D. Entian, and D. Mecke. 1985. The primary structure of the yeast hexokinase PII gene (HXK2) which is responsible for glucose repression. Gene 36:105-111.

30. Goldstein, A., and J. O. Lampen. 1975. B-D-Fructofuranoside fructohydrolase from yeast. Methods Enzymol. 42C:504-511.

31. Grutter, M. G., T. M. Gray, L. H. Weaver, T. Alter, K. Wilson, and B. W. Matthews. 1987. Structural studies of mutants of the lysozyme of bacteriophage T4: the temperature-sensitive mutant protein Thr157 $\rightarrow$ Ile. J. Mol. Biol. 197:315-329.

32. Grutter, M. G., R. B. Hawkes, and B. W. Matthews. 1979. Molecular basis of thermostability in the lysozyme from bacteriophage T4. Nature (London) 277:667-669.

33. Grutter, M. G., L. H. Weaver, T. M. Gray, and B. W. Matthews. 1983. Structure, function, and evolution of the lysozyme from bacteriophage T4, p. 356-360. In C. K. Matthews, E. M.
Kutter, G. Mosig, and P. B. Berget (ed.), Bacteriophage T4. American Society for Microbiology, Washington, D.C.

34. Haltiner, M., T. Kempe, and R. Tjian. 1985. A novel strategy for constructing clustered point mutations. Nucleic Acids Res. 13:1015-1025.

35. Hecht, M. H., H. C. M. Nelson, and R. T. Sauer. 1983. Mutations in $\lambda$ repressor's amino terminal domain: implications for protein stability and DNA binding. Proc. Natl. Acad. Sci. USA 80:2676-2680.

36. Hecht, N. H., J. M. Sturtevant, and R. T. Sauer. 1984. Effect of single amino acid replacements on the thermal stability of the $\mathrm{NH}_{2}$-terminal domain of phage $\lambda$ repressor. Proc. Natl. Acad. Sci. USA 81:5685-5689.

37. Hofiman, C. S., and F. Winston. 1987. A ten-minute DNA preparation from yeast efficiently releases autonomous plasmids for transformation of Escherichia coli. Gene 57:267-272.

38. Ito, H., Y. Fukuda, K. Murata, and A. Kimura. 1983. Transformation of intact yeast cells treated with alkali cations. J. Bacteriol. 153:163-168.

39. Kopetzki, E., K.-D. Entian, and D. Mecke. 1985. Complete nucleotide sequence of the hexokinase PI gene (HXKI) of Saccharomyces cerevisiae. Gene 39:95-102.

40. Korneluk, R. G., F. Quan, and R. A. Gravel. 1985. Rapid and reliable dideoxy sequencing of double stranded DNA. Gene 64:317-323.

41. Kunes, S., H. Ma, K. Overbye, M. S. Fox, and D. Botstein. 1987. Fine structure recombinational analysis of cloned genes using yeast transformation. Genetics 115:73-81.

42. Kuo, C., and J. L. Campbell. 1983. Cloning of Saccharomyces cerevisiae DNA replication genes: isolation of the $C D C 8$ gene and two genes that compensate for the $c d c 8-1$ mutation. Mol. Cell. Biol. 3:1730-1337.

43. Lobo, Z., and P. K. Maitra. 1977. Genetics of yeast hexokinases. Genetics 86:727-744.

44. Lobo, Z., and P. K. Maitra. 1977. Physiological role of glucosephosphorylating enzymes in Saccharomyces cerevisiae. Arch. Biochem. Biophys. 182:639-645.

45. Lowry, O. H., N. J. Rosebrough, A. L. Farr, and R. J. Randall. 1951. Protein measurement with the Folin phenol reagent. J. Biol. Chem. 193:265-275.

46. Ma, H., L. M. Bloom, C. T. Walsh, and D. Botstein. 1989. The residual enzymatic phosphorylation activity of hexokinase II mutants is correlated with glucose repression in Saccharomyces cerevisiae. Mol. Cell. Biol. 9:5643-5649.

47. Ma, H., and D. Botstein. 1986. Effects of null mutations in the hexokinase genes of Saccharomyces cerevisiae on catabolite repression. Mol. Cell. Biol. 6:4046-4052.

48. Ma, H., S. Kunes, P. J. Schatz, and D. Botstein. 1987. Plasmid construction by homologous recombination in yeast. Gene 58:201-216.

49. Maitra, P. K. 1975. Glucokinase from yeast. Methods Enzymol. 42:25-30.

50. Maitra, P. K., and Z. Lobo. 1983. Genetics of yeast glucokinase. Genetics 105:501-515.

51. McDonald, R. C., T. A. Steitz, and D. M. Engelman. 1979. Yeast hexokinase in solution exhibits a large conformational change upon binding glucose or glucose-6-phosphate. Biochemistry 18:338-342.

52. Muratsubaki, H., and T. Katsume. 1979. Distribution of hexokinase isoenzymes depending on a carbon source in Saccharomyces cerevisiae. Biochem. Biophys. Res. Commun. 86:10301036.

53. Neff, N. F., J. H. Thomas, P. Grisafi, and D. Botstein. 1983. Isolation of the $\beta$-tubulin gene from yeast and demonstration of its essential function in vivo. Cell 33:211-219.

54. Nelson, H. C. M., and R. T. Sauer. 1986. Interaction of mutant $\lambda$ repressors with operator and non-operator DNA. J. Mol. Biol. 192:27-38.

55. Otieno, S., A. K. Bhargava, D. Serelis, and E. A. Barnard. 1977. Evidence for a single essential thiol in the yeast hexokinase molecule. Biochemistry 16:4249-4255.

56. Pakula, A. A., V. B. Young, and R. T. Sauer. 1986. Bacteriophage $\lambda$ cro mutations: effects on activity and intracellular 
degradation. Proc. Natl. Acad. Sci. USA 83:8829-8833.

57. Philips, M., D. B. Pho, and L.-A. Pradel. 1979. An essential arginyl residue in yeast hexokinase. Biochim. Biophys. Acta 566:296-304.

58. Pho, D. B., C. Roustan, A. N. T. Tot, and L.-A. Pradel. 1977. Evidence for an essential glutamyl residue in yeast hexokinase. Biochemistry 16:4533-4537.

59. Purich, D. L., H. J. Fromm, and F. B. Rudolph. 1973. The hexokinases: kinetic, physical, and regulatory properties. Adv. Enzymol. 39:249-326.

60. Rose, M., and D. Botstein. 1983. Structure and function of the yeast URA3 gene. Differentially regulated expression of hybrid $\beta$-galactosidase from overlapping coding sequences in yeast. $\mathrm{J}$. Mol. Biol. 170:883-904.

61. Rose, M., P. Grisafi, and D. Botstein. 1984. Structure and function of the yeast URA3 gene: expression in Escherichia coli. Gene 29:113-124.

62. Rose, M., and F. Winston. 1984. Identification of a Ty insertion within the coding sequence of the $S$. cerevisiae URA3 gene. Mol. Gen. Genet. 193:557-560.

63. Sanger, F., S. Nicklen, and A. R. Coulson. 1977. DNA sequencing with chain-terminating inhibitors. Proc. Natl. Acad. Sci. USA 74:5463-5467.

64. Sherman, F., G. R. Fink, and C. W. Lawrence. 1978. Laboratory manual for a course, methods in yeast genetics, revised ed. Cold Spring Harbor Laboratory, Cold Spring Harbor, N.Y.

65. Shortle, D., P. Grisafi, S. J. Benkovic, and D. Botstein. 1982. Gap misrepair mutagenesis: efficient site-directed induction of tran- sition, transversion, and frameshift mutations in vitro. Proc. Natl. Acad. Sci. USA 79:1588-1592.

66. Stachelek, C., J. Stachelek, J. Swan, D. Botstein, and W. Konigsberg. 1986. Identification, cloning and sequence determination of genes specifying hexokinase $A$ and $B$ from yeast. Nucleic Acids Res. 14:945-963.

67. Steitz, T. A., W. F. Anderson, R. J. Fletterick, and C. M. Anderson. 1977. High resolution crystal structures of yeast hexokinase complexes with substrates, activators, and inhibitors. J. Biol. Chem. 252:4494-4500.

68. Struhl, K. 1985. Naturally occurring poly (dA-dT) sequences are upstream promoter elements of constitutive transcription in yeast. Proc. Natl. Acad. Sci. USA 82:8419-8423.

69. Trayser, K. A., and S. P. Colowick. 1961. Properties of crystalline hexokinase from yeast. I. Analysis for possible co-factors. Arch. Biochem. Biophys. 94:156-160.

70. Trayser, K. A., and S. P. Colowick. 1961. Properties of crystalline hexokinase from yeast. II. Studies on ATP-enzyme interaction. Arch. Biochem. Biophys. 94:161-168.

71. Trayser, K. A., and S. P. Colowick. 1961. Properties of crystalline hexokinase from yeast. III. Studies on glucose-enzyme interaction. Arch. Biochem. Biophys. 94:169-176.

72. Viola, R. E., and W. W. Cleland. 1978. Use of $\mathrm{pH}$ studies to elucidate the chemical mechanism of yeast hexokinase. Biochemistry 17:4111-4117.

73. Zimmermann, F. K., and I. Scheel. 1977. Mutants of Saccharomyces cerevisiae resistant to carbon catabolite repression. Mol. Gen. Genet. 154:75-82. 